\title{
Investigation of water sorption and aluminum releases from high viscosity and resin modified glass ionomer
}

\author{
Numan Aydın ${ }^{1}$, Serpil Karaoğlanoğlu ${ }^{1}$, Elif Aybala-Oktay ${ }^{1}$, Serdar Çetinkaya ${ }^{2}$, Onur Erdem ${ }^{2}$ \\ ${ }^{1}$ DDS, PhD. University of Health Sciences, Gulhane Faculty of Dentistry, Department of Restorative Dental Treatment, Ankara, \\ Turkey \\ ${ }^{2} \mathrm{PhD}$. University of Health Sciences, Gulhane Faculty of Pharmacy, Department of Toxicology, Ankara, Turkey
}

Correspondence:

University of Health Sciences

Gulhane Faculty of Dentistry

Department of Restorative Dental Treatment

Etlik 06018 Ankara, Turkey

dt_numan@hotmail.com

Aydın N, Karaoğlanoğlu S, Aybala-Oktay E, Çetinkaya S, Erdem O. Investigation of water sorption and aluminum releases from high viscosity and resin modified glass ionomer. J Clin Exp Dent. 2020;12(9):e844-51.

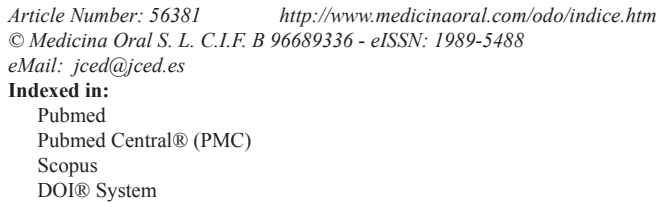

\begin{abstract}
Background: High viscosity glass ionomer cement (HVGIC) and resin-modified glass ionomer cement (RMGIC) have recently been clinically preferred thanks to their numerous advantages. However, initial moisture contamination has a negative effect on the mechanical and physical properties of these cements. The aim of this study was in vitro of HVGICs and RMGICs, with and without surface protection, on water sorption, solubility and release of aluminum.

Material and Methods: In this study, as HVGICs; Equia Forte, IonoStar Plus, Riva Self Cure; as RMCIS, Ionolux and Riva Light Cure; and as control, Z250 universal composite was used. Equia coat, Voco varnish and Riva coat were chosen as surface protective. Water sorption and solubility levels of the samples were measured according to ISO 4049:2009. Al levels released from samples were determined by graphite furnace atomic absorption spectroscopy (GFAAS) for 7, 14 and 21 days. Statistical evaluation of the results was made using one-way variance analysis (ANOVA) and Tukey post-hoc test $(p<0.05)$.

Results: RMGICs from restorative materials showed more water absorption than HVGICs, but no differences in solubility. Among the materials tested, the water absorption values of the HVGIC and RMGIC materials without surface protection were higher than those with the surface protection $(p<0.001)$.

Conclusions: It was determined that the Al release of HVGIC and RMGIC groups with the surface protection were lower in all time periods than the groups without surface protection $(p<0.001)$. The application of surface protection effectively reduced water sorption and Al release from HVGICs and RMGICs.
\end{abstract}

Key words: Highly viscous glass ionomer cement, resin coating, aluminum release, water sorption, solubility. 


\section{Introduction}

Glass ionomer cements were first introduced to dentistry by Wilson and Kent in 1972 (1). Subsequently, resin-modified glass ionomer cements (RMGIC) were introduced into the market. This restorative materials powder part is composed of fluoroaluminosilicate glass powders, and the liquid part is composed of HEMA (2-hydroxyethyl methacrylate), methacrylate groups, polyacrylic acid, tartaric acid and water $(2,3)$.

In recent years, high viscosity glass ionomer cements (HVGIC) have been developed in order to improve the weak mechanical properties of conventional CGICs and wear resistance against occlusal forces in clinical applications and to extend the indication areas limited to class I and class V restorations (3). In addition, these materials are intended to be an alternative to composite resin and amalgam as the material in permanent restorations of the teeth. Wear resistance, surface hardness, bending and compression resistance of these cements, whose hardening mechanisms are similar to CGICs, have been increased. The fluorides and biocompatibility of these cements are similar to CGICs (4). Water sorption, which affects the physical, chemical and mechanical properties of all dental restorative materials, is one of the factors that affect the clinical success of dental restorative materials and cannot be kept under control completely. The hypersensitivity of CGICs to moisture is also evident in HVGIC and RMGIC. Due to the hydrolysis of the cement matrix, water sorption leads to the degradation of cements in time and leads to the loss of surface properties, edge integrity, aesthetic appearance and consequently increase of the deteriorations in restorations $(5,6)$. In order to eliminate these disadvantages, it is recommended to provide a protection with a surface covering application for periods ranging from 1 hour to 2 weeks, in order to protect from moisture interaction after dental restorations are made $(7,8)$. With the developments in surface covering systems, light cured surface coverings have emerged as optimal surface protection agents. In recent years, nano-filler surface coverings combined with HVGICs have been introduced to the market.

The biocompatibility of CGICs are significantly influenced by the release of fluorine (F) and aluminum (Al) from their structure. $\mathrm{Al}$ is an element which is taken into the organism from different sources and has potentially toxic effects (9). There are studies about the association of $\mathrm{Al}$ with the pathogenesis of Alzheimer's disease. Furthermore, it has been reported to play a role in other neurological diseases including Parkinson, pathogenesis of amyotrophic lateral sclerosis, skeletal and hematological diseases $(10,11)$. After restoration, fluoride release of the glass ionomer cements used in restorative dentistry into the mouth, as well as other elements such as aluminum, calcium $(\mathrm{Ca})$ and sodium $(\mathrm{Na})$ are available in literature $(12,13)$. In the studies, it was found that the $\mathrm{Al}$ ions on the cement surface were released at most at the very first day during the polymerization of CGICs, and the rest were trapped in the depths of the matrix (13). In the researes, the amount of fluoride released from CGIS was investigated. However, water sorption, dissolution and release of $\mathrm{Al}$ were neglected when these materials were used with and without surface protection. The aim of this study was in vitro examination of the effect of usage of HVGICs and RMGICs, with and without surface protection, on water sorption, solubility and release of aluminum.

\section{Material and Methods}

In our study as HVGIC; Equia Forte (GC Corporation, Japan), IonoStar Plus (VOCO GmbH, Germany), Riva Self Cure (SDI, Australia) and as RMGIC; Ionolux (VOCO GmbH, Germany) and Riva Light Cure (SDI, Australia) was used (Table 1). Each material's same brand protector was selected as the surface protector (Equia coat, Voco varnish and Riva coat). The Filtek Z250 (3M ESPE, USA) universal composite was used as a control (Table 1).

-Preparation of samples

Each of the materials examined in this study was prepared using 10 sample $(15 \times 1 \mathrm{~mm})$ silicone modes as specified in ISO 4049:2009 (14), for polymerization of HVGICs, it was polymerized as long as the polymerization period suggested by the manufacturer. For polymerization of RMCIS and composite material, they were polymerized for the period suggested by the manufacturer (20 sec.), using LED light source (DTE LUX E, Germany, $1200 \mathrm{mw} / \mathrm{cm}^{2}$ ). The prepared samples were randomly divided into two groups (n:5) with and without surface protection. Each material's same brand surface protection material was chosen as surface protection material. They were polymerized with the same led light source in accordance with the recommendations of the manufacturer (10 sec.).

-Water sorption and solubility test

Water sorption and solubility levels of the samples were performed as specified in ISO 4049:2009 (14). Prepared samples are placed in desiccator containing anhydrous calcium chloride and kept for 22 hours at $(37 \pm 1)^{\circ} \mathrm{C}$, then at a similar desiccator for 2 hours at $(23 \pm 2)^{\circ} \mathrm{C}$. The weight of each sample taken from the desiccator was measured (within $15 \mathrm{sec}$.) with precision electric scales (Mettler AT201, Switzerland). This was continued until a constant weight value was obtained $(0.1 \mathrm{mg})$ and the measured values were recorded. (M1)

Samples were kept in $10 \mathrm{~mL}$ of ultrapure water (Veolia, UK) in incubator (Heraeus D- 6450 Hanau, California) at $37+1$ oC for 7 days after the measurement and then removed from the water. Their surfaces were dehumidified with the blotting paper and then re-weighed. (M2) 
Table 1: HVGICs, RMGICs and surface protectors used in the study.

\begin{tabular}{|c|c|c|c|c|}
\hline \multirow[t]{2}{*}{ Materials } & \multirow[t]{2}{*}{ Shade / Lot no } & \multirow[t]{2}{*}{ Type of GIC } & \multicolumn{2}{|r|}{ Composition } \\
\hline & & & $\begin{array}{c}\text { Capsule- } \\
\text { Compartment } 1\end{array}$ & Capsule-Compartment 2 \\
\hline $\begin{array}{l}\text { GC Equia Forte } \\
\text { (GC Corporation, } \\
\text { Tokio, Japan) }\end{array}$ & $\begin{array}{c}\text { Shade A2 } \\
\text { Lot: } 160218 \mathrm{a}\end{array}$ & $\begin{array}{l}\text { Highly } \\
\text { viscous }\end{array}$ & $\begin{array}{l}\text { fluoro-aluminosilicate } \\
\text { glass, iron (III) oxide } \\
<0.5\end{array}$ & polybasic carboxylic acid 5\% -10\% \\
\hline $\begin{array}{l}\text { Riva Self Cure } \\
\text { (SDI, Bayswater, } \\
\text { Australia) }\end{array}$ & $\begin{array}{l}\text { Shade A2 } \\
\text { Lot: } \\
\text { B1711223F }\end{array}$ & $\begin{array}{l}\text { Highly } \\
\text { viscous }\end{array}$ & $\begin{array}{c}\text { fluoro-aluminosilicate } \\
\text { glass } 90 \%-95 \%\end{array}$ & $\begin{array}{c}\text { acrylic acid homopolymer } 20 \%-30 \%, \\
\text { tartaric acid } 10 \%-15 \%\end{array}$ \\
\hline $\begin{array}{l}\text { Riva Light Cure } \\
\text { (SDI, Bayswater, } \\
\text { Australia) }\end{array}$ & $\begin{array}{c}\text { Shade A2 } \\
\text { Lot: } \\
\text { K1803093EG }\end{array}$ & $\begin{array}{c}\text { Resin- } \\
\text { modified }\end{array}$ & $\begin{array}{c}\text { glass powder } 93 \% \text { - } \\
100 \%\end{array}$ & $\begin{array}{c}\text { acrylic acid homopolymer } 15 \%-25 \% \text {, } \\
\text { HEMA } 15 \%-25 \% \text {, tartaric acid 1-5\%, } \\
\text { dimethacrylate cross-linker } 10 \% 25 \% \text {, } \\
\text { acid monomer } 10 \%-20 \%\end{array}$ \\
\hline $\begin{array}{l}\text { IonoStar Plus } \\
\text { (VOCO GmbH, } \\
\text { Cuxhaven, } \\
\text { Germany) }\end{array}$ & $\begin{array}{c}\text { Shade A2 } \\
\text { Lot: } 1805362\end{array}$ & $\begin{array}{l}\text { Highly } \\
\text { viscous }\end{array}$ & $\begin{array}{l}\text { fluoro-aluminosilicate } \\
\text { glass } 50 \%-100 \%\end{array}$ & $\begin{array}{c}\text { polyacrylic acid } 10 \%-25 \%, \\
\text { tartaric acid }<2.5 \%\end{array}$ \\
\hline $\begin{array}{l}\text { Ionolux (VOCO } \\
\text { GmbH, Cuxhaven, } \\
\text { Germany) }\end{array}$ & $\begin{array}{c}\text { Shade A2 } \\
\text { Lot: } 1806423\end{array}$ & $\begin{array}{c}\text { Resin- } \\
\text { modified }\end{array}$ & $\begin{array}{l}\text { fluoro-aluminosilicate } \\
\text { glass } 50 \%-100 \%\end{array}$ & polyacrylic acid $2.5 \%-5 \%$ \\
\hline $\begin{array}{l}\text { Filtek Z250 (3M } \\
\text { ESPE, St. Paul } \\
\text { USA) }\end{array}$ & $\begin{array}{c}\text { Shade A2 } \\
\text { Lot: N904868 }\end{array}$ & $\begin{array}{c}\text { Resin } \\
\text { (Microhybrid) }\end{array}$ & $\begin{array}{r}0.01-3.5 \mathrm{~mm} z \\
\text { Bis-C }\end{array}$ & $\begin{array}{l}\text { renia-silica (filler weight } 82 \% \text { ) } \\
\text { AA, UDMA, Bis-EMA }\end{array}$ \\
\hline $\begin{array}{l}\text { Equia Coat }(\mathrm{GC} \\
\text { Europe, Leuven, } \\
\text { Belgium) }\end{array}$ & Lot: 1504171 & $\begin{array}{l}\text { Light-Cured } \\
\text { (Nano-filled) }\end{array}$ & $\begin{array}{r}\text { Methyl methacryl } \\
\text { urethane metha }\end{array}$ & $\begin{array}{l}\text { e, colloidal silica, camphorquinone, } \\
\text { ylate, phosphoric ester monomer }\end{array}$ \\
\hline $\begin{array}{l}\text { Final varnish LC } \\
\text { (VOCO GmbH, } \\
\text { Cuxhaven, } \\
\text { Germany) }\end{array}$ & Lot: 1740435 & Light-Cured & 1,6-hexane & $\begin{array}{l}\text { S-GMA } 25 \%-50 \% \\
\text { ylbismethacrylate } 20 \%-30 \%\end{array}$ \\
\hline $\begin{array}{l}\text { Riva Coat (SDI, } \\
\text { Bayswater, } \\
\text { Australia) }\end{array}$ & Lot: 170113 & Light-Cured & $\begin{array}{r}\text { Triethylenes } \\
\text { Diuretha }\end{array}$ & $\begin{array}{l}\text { ycoldimethacrylate } 20 \%-30 \% \\
\text { edimethacrylate } 60 \%-70 \%\end{array}$ \\
\hline
\end{tabular}

"BisGMA: Bisfenol diglisidilmetakrilat, BisEMA: bisfenol-etilmetakrilat, UDMA: üretan dimetakrilat, PEGDMA: polietilen glikol dimethacrylate, TEGDMA: trietilenglikol dimethacrylate.

The weighed samples were placed in the desiccator with anhydrous calcium chloride and was kept for 22 hours at $(37 \pm 1)^{\circ} \mathrm{C}$, then kept at the desiccator for 2 hours at $(23 \pm 2)^{\circ} \mathrm{C}$. The weight of each sample taken from the desiccator was measured (within $15 \mathrm{sec}$.) with precision electric scales (Mettler AT201, Switzerland). (M3)

In accordance with the ISO 4049:2009 (14), values for the water sorption (Wsp) and the solubility (Wsl) at specific times were calculated using the following equations, respectively:

$\mathrm{Wsp}=[\mathrm{M} 2-\mathrm{M} 3] \div \mathrm{V}$ and $\mathrm{Wsl}=[\mathrm{M} 1-\mathrm{M} 3] \div \mathrm{V}$

$\mathrm{M} 1=$ is the conditioned mass, in micrograms, prior to immersion in water $(\mu \mathrm{g})$

M2 $=$ is the mass of the specimen, in micrograms, after immersion in water for 7 days $(\mu \mathrm{g})$
$\mathrm{M} 3=$ is the mass of the reconditioned specimen, in micrograms $(\mu \mathrm{g})$

$\mathrm{V}=$ is the volume of the specimen, in cubic millimetres $\left(\mathrm{mm}^{3}\right)$

-Determination of Al levels

After measurement of the first dry weight of samples (M1, the samples were incubated in the incubator (Heraeus D-6450 Hanau, California) during the 21-day testing period in $10 \mathrm{~mL}$ of ultrapure water (Veolia, UK) at $37 \pm 1^{\circ} \mathrm{C}$. The samples were collected for the first 7 days and then on the 14th and 21st days and the samples were transferred to $10 \mathrm{~mL}$ of propylene tubes. Water samples were kept at $4^{\circ} \mathrm{C}$ until the analysis time. Fresh ultrapure water was added in $10 \mathrm{~mL}$ volume to replace the water samples taken. This was done on days 7,14 and 21. The 
values of $\mathrm{Al}$ in the ultrapure water were measured at the beginning and after each measurement process.

Al levels released from the samples were determined using Graphite Furnace Atomic Absorption Spectrometry (GFAAS) (Perkin Elmer Analyst 800, USA). Argon gas was used as the carrier gas in the analyzes. $1 \mathrm{~g} / \mathrm{L}$ standard Al solution (Merck) was used for calibration. A $50 \mathrm{ng} / \mathrm{mL}$ stock solution was prepared from this solution with $0.2 \%$ HNO3 (Merck). The prepared solution was arranged to correspond to the concentration of 10,20 , $30,40,50 \mathrm{ng} / \mathrm{mL}$ for use in the calibration process by system software during the analysis. Calibration graph was prepared with the help of absorbance values corresponding to the concentration.

-Statistical Analysis

Statistical data analysis was performed using SPSS 22.0 Statistical Program (SPSS Inc., Chicago, USA). The water sorption and solubility and Al release of the HVGICs and RMGICs used in the study were evaluated by using one-way variance analysis (ANOVA) and Tukey posthoc test. $P<0.05$ was considered to indicate statistical significance.

\section{Results}

Average water sorption values and standard deviations obtained as a result of our study are shown in table 2-3. Statistically significant differences were found between the water sorption values of HVGIC and RMGIC $(p<0.001)$. In addition, it was determined that all groups showed more water sorption than the control group $(p<0.05)$. Maximum water sorption was detected in RMCIS groups at Riva Light Cure $\left(11.76 \mu \mathrm{g} / \mathrm{mm}^{3}\right)$ and Ionolux $\left(11.35 \mu \mathrm{g} / \mathrm{mm}^{3}\right)$, while the lowest water sorption value $\left(9.66 \mu \mathrm{g} / \mathrm{mm}^{3}\right)$ detected in Equia Forte, which is HVGIC (Table 2).
HVGIC and RMGIC groups treated with surface protectors showed less water sorption than the non-protective group and more water absorption than the control group $(p<0.05)$. Riva Light Cure + Riva Coat, which is RMGIC, has shown the highest water absorption value $(10.78 \mu \mathrm{g} / \mathrm{mm} 3)$, whereas Equia Forte + Equia Coat, which is HVGIC, has shown the lowest $(6.86 \mu \mathrm{g} / \mathrm{mm} 3)$ water sorption value (Table 2, Fig. 1).

When HVGIC and RMGIC groups were evaluated in terms of water sorption, there were no statistically significant difference between the Riva Light Cure and Riva Self Cure groups that have been applied with surface protection $(p>0.05)$. However, statistically significant differences $(p<0.05)$ were found between the Ionolux, IonoPlus Star, and Equia Forte groups that had been applied with surface protection (Table 2).

When HVGIC and RMGIC solubility values were examined, there was no statistically significant difference, although RMGICs had shown more solubility than HV$\operatorname{GIC}(p>0.05)$. There was no statistically significant difference when the groups of these cements with surface protection and without surface protection were compared $(p>0.05)$. A statistically significant difference $(p<0.001)$ was observed between the control group and all the other groups with and without surface protection (Table 2).

When the Al releases of restorative materials of HVGIC and RMGIC were evaluated according to weeks, the difference was statistically significant $(p<0.001)$. At the end of the three weeks, the most Al release was detected with Riva Self Cure 0.831 ppm (parts per million), which is HVGIC, while the least Al release was detected Ionolux $0.089 \mathrm{ppm}$, which is a surface protection applied RMGIC. Besides, it was determined that groups of Riva Light Cure and Riva Self-Cure, Ionolux, IonoPlus Star and Equia Forte, treated with surface protection, releases

Table 2: Effect of HVGIC and RMGIC surface protection application on water sorption and solubility.

\begin{tabular}{|l|c|c|}
\hline Materials Used & $\begin{array}{c}\text { Water sorption } \pm \text { SD } \\
\left(\mu \mathrm{g} / \mathrm{mm}^{3}\right)\end{array}$ & Solubility \pm SD $\left(\mu \mathrm{g} / \mathrm{mm}^{3}\right)$ \\
\hline Riva Light Cure & $11.76 \pm 0.66^{\mathrm{a}}$ & $3.31 \pm 0.53^{\mathrm{a}}$ \\
Riva Light Cure + Riva Coat & $10.78 \pm 0.89^{\mathrm{ab}}$ & $3.05 \pm 0.65^{\mathrm{a}}$ \\
\hline Riva Self Cure & $10.22 \pm 0.73^{\mathrm{ab}}$ & $3.14 \pm 0.50^{\mathrm{a}}$ \\
Riva Self Cure + Riva Coat & $9.99 \pm 0.77^{\mathrm{bc}}$ & $2.76 \pm 0.46^{\mathrm{a}}$ \\
\hline Ionolux & $11.35 \pm 0.26^{\mathrm{ab}}$ & $3.29 \pm 0.11^{\mathrm{a}}$ \\
Ionolux + Voco Varnish & $8.38 \pm 1.18^{\mathrm{cd}}$ & $2.85 \pm 0.57^{\mathrm{a}}$ \\
\hline IonoPlus Star & $10.50 \pm 0.46^{\mathrm{ab}}$ & $3.28 \pm 0.19^{\mathrm{a}}$ \\
IonoPlus Star + Voco Varnish & $7.20 \pm 0.56^{\mathrm{d}}$ & $2.86 \pm 0.28^{\mathrm{a}}$ \\
\hline Equia Forte & $9.66 \pm 0.86^{\mathrm{bc}}$ & $2.32 \pm 0.33^{\mathrm{a}}$ \\
Equia Forte + Equia Coat & $6.68 \pm 0.53^{\mathrm{d}}$ & $1.74 \pm 0.44^{\mathrm{a}}$ \\
\hline Control (Filtek Z250) & $2.40 \pm 0.18^{\mathrm{e}}$ & $0.65 \pm 0.11^{\mathrm{b}}$ \\
\hline
\end{tabular}

* a-e shows the statistical significance between rows. $P<0.05$. 


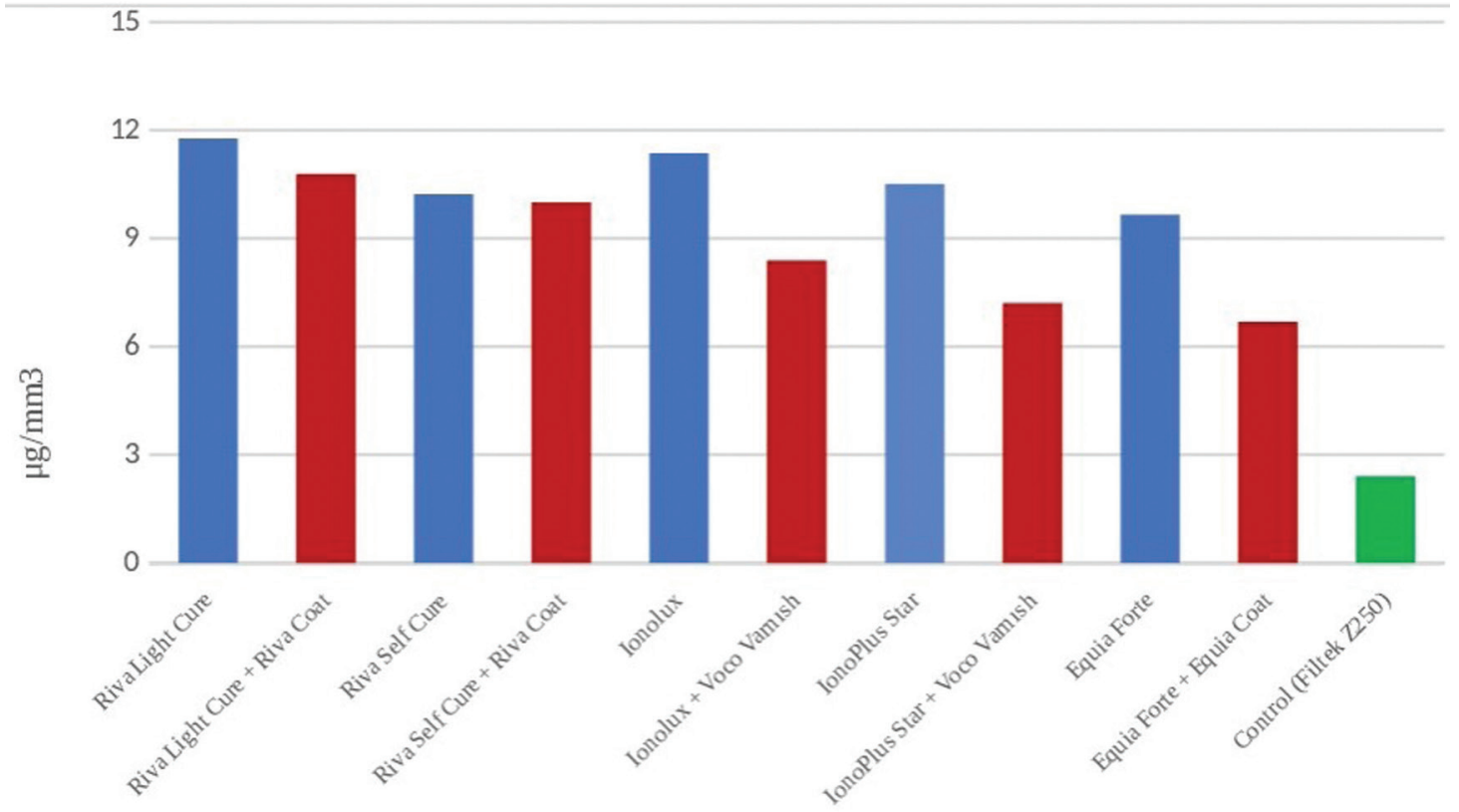

Fig. 1: Water sorption of HVGIC and RMGIC.

less $\mathrm{Al}$ in all time periods than the groups without a surface protection $(p<0.001)$. There was a statistically significant difference $(p<0.001)$ between the control group and the groups with and without surface protection. It was observed that the maximum $\mathrm{Al}$ release was at the first week and decreased as the time period progressed (Table 3, Fig. 2).

\section{Discussion}

HVGICs and RMGICs were produced to overcome the inadequacies of aesthetic appearance of conventional glass ionomer cements, their sensitivity to water and weak mechanical properties and to benefit the clinical advantages of these cements. CGICs are clinically preferred because of their chemical bonding to tooth structures, fluorine release and reminelization $(3,15)$. In spite of many advantages, initial moisture contamination can lead to a reduction in the mechanical and physical properties, deterioration of the matrix connection, coloration and edge breakage (16). The process of water absorption is, at present, explained by two theories. One theory hypothesizes that water molecules diffuse into microvoids where they interact with the resin matrix. The second theory proposes that water molecules bond to hydrophilic groups of the cement, resulting in hygroscopic expansion and increase of weight (17).

Table 3: Time dependent Al release from HVGIC and RMGIC.

\begin{tabular}{|c|c|c|c|c|c|}
\hline Materials & 1st week & 2nd week & 3rd week & Total & $\boldsymbol{P}$ \\
\hline Riva Light Cure & $0.490^{\mathrm{a}}$ & $0.089^{\mathrm{a}}$ & $0.072^{\mathrm{a}}$ & 0.651 & 0.000 \\
\hline Riva Light Cure + Riva Coat & $0.401^{\mathrm{b}}$ & $0.119^{\mathrm{b}}$ & $0.079^{\mathrm{b}}$ & 0.599 & 0.000 \\
\hline Riva Self Cure & $0.566^{\mathrm{c}}$ & $0.166^{\mathrm{c}}$ & $0.099^{\mathrm{c}}$ & 0.831 & 0.000 \\
\hline Riva Self Cure + Riva Coat & $0.385^{\mathrm{d}}$ & $0.071^{\mathrm{d}}$ & $0.056^{\mathrm{d}}$ & 0.512 & 0.000 \\
\hline Ionolux & $0.210^{\mathrm{e}}$ & $0.048^{\mathrm{e}}$ & $0.063^{\mathrm{e}}$ & 0.321 & 0.000 \\
\hline Ionolux + Voco Varnish & $0.035^{\mathrm{f}}$ & $0.030^{\mathrm{f}}$ & $0.019^{\mathrm{f}}$ & 0.089 & 0.000 \\
\hline IonoPlus Star & $0.433^{\mathrm{g}}$ & $0.100^{\mathrm{g}}$ & $0.081^{\mathrm{b}}$ & 0.614 & 0.000 \\
\hline IonoPlus Star + Voco Varnish & $0.108^{\mathrm{h}}$ & $0.048^{\mathrm{eg}}$ & $0.044^{\mathrm{g}}$ & 0.200 & 0.000 \\
\hline Equia Forte & $0.403^{\mathrm{b}}$ & $0.095^{\mathrm{a}}$ & $0.070^{\mathrm{a}}$ & 0.568 & 0.000 \\
\hline Equia Forte + Equia Coat & $0.098^{\mathrm{h}}$ & $0.062^{\mathrm{h}}$ & $0.045^{\mathrm{h}}$ & 0.205 & 0.000 \\
\hline Control (Filtek Z250) & $0.020^{\mathrm{i}}$ & $0.003^{\mathrm{i}}$ & $0.007^{\mathrm{i}}$ & 0.030 & 0.000 \\
\hline
\end{tabular}

* a-i shows the statistical significance between the rows. Al values are shown in ppm. $P<0.05$. 


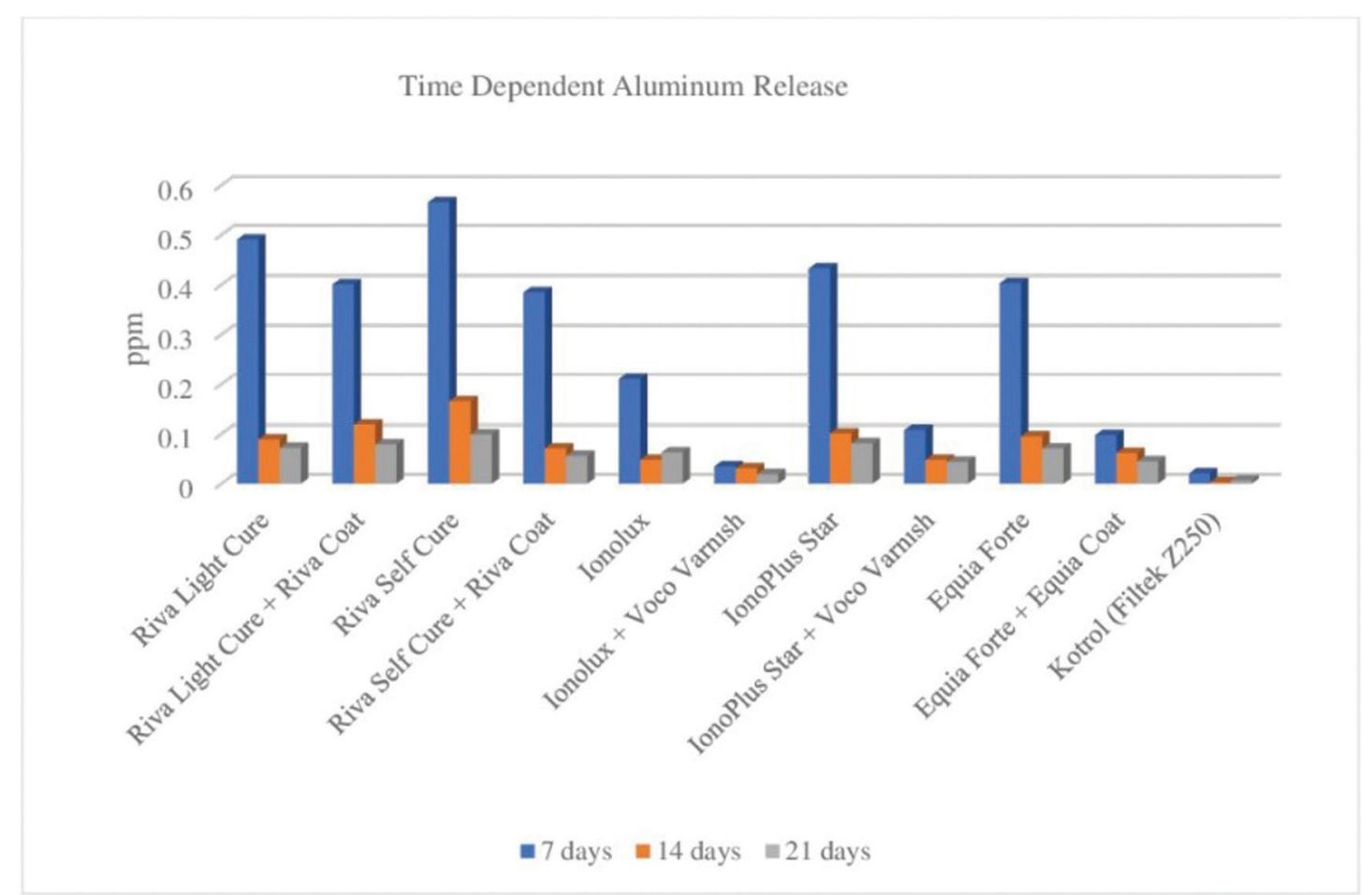

Fig. 2: Time dependent Al release of HVGIC and RMGIC.

In their study on the water absorption and solubility of glass ionomer cements, Lima et al. (18) found that RMGIC (Vitramer), the product of the same brand, showed more water absorption and solubility than CGIC (Ketac Molar Easymix). Cefaly et al. (19) reported in their studies that RMGIC cements showed more water absorption than composites. Studies in literature have attributed RMGICs' having higher water absorption than that of CGIC (19) to the hydrophilicity of 2-hydroxyethylmethacrylate (HEMA) in the structure of RMGICs (20). Beriat and Nalbant (21) reported in their studies on the water absorption of RMGICs and HEMA release that there was a positive correlation between water absorption and HEMA release. In our study, RMGICs without surface protection (Riva Light Cure and Ionolux) were found to exhibit the highest water absorption and solubility.

Various surface preservatives such as light-cured bonding agent or varnish have been recommended to overcome the initial problems related to water absorption and dehydration in CGICs. After these recommendations, light-curing resin preservatives started to be applied on restorations (22) and in recent years HVGICs with capsule form and nano-filled resin coatings were made available to surgeons. In in vitro studies, it is stated that the application of surface protection to CGICs positively affects the polymerization process by maintaining water balance, control the hygroscopic expansion and increases its durability (22-24). In our study, nano-filled surface protector application on HVGIC and RMGIC was found to reduce water sorption, while HVGIC Equia Forte + Equia Coat showed the lowest water sorption $\left(6.68 \mu \mathrm{g} / \mathrm{mm}^{3}\right)$ values. While surface protectors Voco Varnish and Equia Coat reduces water sorption of HVGICs and RMGICs $(p<0.05)$, there was no statistically significant difference in the sorption of water in Riva Coat applied groups (Riva Light Cure, Riva Self Cure) $(p>0.05)$. In addition, it was found that surface protection application did not make a statistically significant difference while decreasing the solubility of HVGICs and RMGICs $(p<0.05)$.

Surface protection application affects the water sorption of dental restorative material as well as other physical properties. Karaoglanoglu et al. (25) in their studies on the effects of surface protection application on dye sorption on glass ionomer, resin modified ionomer and polyacid modified composite resins, they stated that the use of surface protection significantly reduced the sorption of dye. Kanik et al. (26) stated that application of surface protective resin (EQUIA Coat) on HVGICs (EQUIA Fil and Riva Self Cure) increased the wear resistance of the material. Bonifacio et al. (27) also found that coating CIS (Fuji IX GP Extra and Ketac Molar) with resin (G coat) increased the wear resistance and bending strength of the material.

$\mathrm{Al}$, which is the main component of HVGICs and RMGICs, plays an important role in acid-base reaction during the polymerization of cement and $\mathrm{Al}$ in the superficial layer is released (28). Studies have shown that $\mathrm{Al}$ accumulates in human body tissues such as brain, 
bone, liver and kidney $(29,30)$. It has been shown that $\mathrm{Al}$ which is accumulated in bone tissue retards the formation and growth of hydroxyapatite crystals and may impair the process of mineralization (31). These days, it is widely accepted as a neurotoxicant now and may induce its toxic manifestations by exacerbating oxidative stress in brain. Moreover, mitochondria associated dysfunctions may also be regarded as causative factor for mediating $\mathrm{Al}$ toxicity (10). Various studies have indicated neuropathological, neurobehavioral, neurophysical and neurochemical changes following $\mathrm{Al}$ exposure $(32,33)$.

Gjorgievska et al. (34) has shown in their studies that $\mathrm{Al}$ released by glass-ionomer and RMGIC fillings is absorbed by the tooth. Various types of tooth were restored by commercial glass-ionomer restorative materials, and then the release of aluminum and fluoride into artificial saliva was determined. Results showed that the lowest levels of $\mathrm{Al}$ were found in solutions where immature permanent teeth were stored than deciduous teeth, from which it was concluded that the immature permanent teeth have a higher affinity for aluminum than deciduous teeth (34).

Czarnecka et al. (35) in their study on ion release of glass ionomer cements, stated that the release of $\mathrm{Al}$ could be related to fluorine complexes, and found that aluminum, phosphorus and fluoride ions were released at all-time intervals and this release had a tendency to decrease over time. They also stated that the maximum release of $\mathrm{Al}$ was in the first week (41.2 ppm) and in the 4th week, the release of $\mathrm{Al}$ was reduced to a level (1.17 ppm) to be neglected. In another study by Czarnecka et al. (36) they have found that Ketac Endo (3.70 ppm) do more $\mathrm{Al}$ release than the Ketac Molar (1.73 ppm) and Fuji IX $(1.71 \mathrm{ppm})$ in the analysis of glass ionomer cements in distilled water at the 1 st week.

In the study of Okte et al. (37) on the fluorine and $\mathrm{Al}$ release of restorative materials using ion chromatography, the only observable aluminum release was from the conventional and resin-modified GICs during the first day in double-distilled water. In addition, the RMGIC Vitremer released a higher amount of aluminum than the conventional GIC Kavitan Plus. Savarino et al. (9) found that CGICs and RMGICs released more $\mathrm{Al}$ than the compomer in their study on the fluorine and $\mathrm{Al}$ release of compomer, conventional and resin-modified glass ionomer cements. They also reported that the ion release was highest during the initial polymerization (9). In our study in the distilled water at the end of the 1st, 2nd and 3 rd weeks, the highest $\mathrm{Al}$ release was found in HVGIC Riva Self Cure $(0.831 \mathrm{ppm})$ and the lowest in RMGIC Ionolux $(0.321 \mathrm{ppm})$. However, $\mathrm{Al}$ release of HVGICs and RMGICs were found to be statistically higher than traditional composite (Filtek Z250) $(p<0.001)$. In addition, similar to the results of other studies $(9,35)$. Al release in all groups were found to be in a downward trend as the time period progressed.
When the studies in the literature are examined, there is no information about the effect of surface protective application on the release of Al. In our study, it was seen that the application of surface protector statistically significantly decreased $(p<0.001)$ the $\mathrm{Al}$ release of HVGICs and RMGICs. In addition, the application of the surface protector decreased $\mathrm{Al}$ release at Ionolux (72.27\%), Equia Forte (63.90\%), IonoPlus Star (67.42\%), Riva Light Cure (38.38\%) and Riva Self Cure (7.98\%). These results suggest that Voco Varnish and Equia Coat are more successful than Riva Coat on preventing $\mathrm{Al}$ release.

It is stated in the literature that glass ionomer cements can inhibit the polymerization reaction as a result of early water absorption (38). The application of effective (Voco Varnish and Equia Coat) surface preservatives on these materials in our study provides better polymerization by reducing water absorption. Enough polymerization of materials results in less $\mathrm{Al}$ release.

\section{Conclusions}

As a result, materials used for restorative purposes are exposed to various factors such as stress, heat changes and chemical agents in the oral environment. As a result of these factors, water sorption, dissolution and release of Al occurs at HVGICs and RMGICs. The use of these materials, which are used extensively in restoration of deciduous and permanent teeth, not only reduces water sorption but also greatly reduces the release of $\mathrm{Al}$, which is harmful to the human body. If the HVGICs and RMGICs are used with a nano surface protector with the correct indication, we think that the clinical use of the restorative material will be longer and will cause the patient the least damage.

\section{References}

1. Wilson AD, Kent BE, Clinton D, Miller RP. The formation and microstructure of dental silicate cements. J Mater Sci. 1972;7:220-38.

2. Nicholson JW. Chemistry of glass-ionomer cements: a review. Biomaterials. 1998;19:485-94.

3. Sidhu SK, Nicholson JW. A review of glass-ionomer cements for clinical dentistry. J Funct Biomater. 2016;7:1-16.

4. Crowley CM, Doyle J, Towler MR, Hill RG, Hampshire S. The influence of capsule geometry amd cement formulation on the apparent viscosity of dental cements. J Dent. 2006;34:566-73.

5. Yap A, Lee CM. Water sorption and solubility of resin-modified polyalkenoate cements. J Oral Rehabil. 1997;24:310-4.

6. Iwami Y, Yamamoto H, Sato W, Kawai K, Torii M, Ebisu S. Weight change of various lightcured restorative materials after water immersion. Oper Dent. 1998:23:132-7.

7. Miyazaki M, Moore BK, Onose H. Effect of surface coatings on flexural properties of glass ionomers. Eur J Oral Sci. 1996;104:600-4. 8. Hotta M, Hirukawa H, Yamamoto K. Effect of coating materials on restorative glass-ionomer cement surface. Oper Dent. 1992;17:57-61. 9. Savarino L, Cervellati M, Stea S, Cavedagna D, Donati ME, Pizzoferrato A, et al. In vitro investigation of aluminum and fluoride release from compomers, conventional and resin-modified glass-ionomer cements: A standardized approach. J Biomater Sci Polymer Edn. 2000; 11:289-600.

10. Kumar V, Gill KD. Oxidative stress and mitochondrial dysfunction in aluminium neurotoxicity and its amelioration: a review. Neurotoxicol. 2014;41:154-66. 
11. Han S, Lemire J, Appanna VP, Christopher A, Zachary C, Vasu DA. How aluminum, an intracellular ROS generator promotes hepatic and neurological diseases: the metabolic tale. Cell Biol Toxicol. 2013;29:75-84

12. Forsten L. Fluoride release and uptake by glass-ionomers and related materials and its clinical effect. Biomaterials. 1998;19:503-8.

13. Nakajima H, Komatsu H, Okabe T. Aluminum ions in analysis of released fluoride from glass ionomers. J Dent. 1997;25:137-44.

14. International Organization for Standardization. ISO 4049:2009 Polymer-based restorative materials. Geneva: ISO; 2009.

15. Kleverlaan CJ, Duinen RNB, Feilzer AJ. Mechanical properties of glass ionomer cements affected by curing methods. Dent Mater. 2004;20:45-0.

16. Lohbauer U. Dental glass ionomer cements as permanent filling materials? - properties, limitations and future trends. Materials. 2010;3:76-96.

17. Muller JA, Rohr N, Fischer J. Evaluation of ISO 4049: water sorption and water solubility of resin cements. Eur J Oral Sci. 2017;125:141-50.

18. Lima RBW, Farıas JFG, Andrade AKM, S1lva FDS da CM, Duarte RM. Water sorption and solubility of glass ionomer cements indicated for atraumatic restorative treatment considering the time and the $\mathrm{pH}$ of the storage solution. Rev Gaúch Odontol. 2018;66:29-34.

19. Cefaly DFG, Wang L, Mello LLCP, Santos JL, Santos JR, Lauris JRP. Water sorption of resin-modified glass-ionomer cements photoactivated with LED. Braz Oral Res. 2006;20:342-6.

20. Mortier E, Gerdolle DA Jacquot B, Panighi MM. Importance of water sorption and solubility studies for couple bonding agent- resin based filling material. Oper Dent. 2004;29: 669-76.

21. Beriata NC, Nalbant D. Water absorption and HEMA release of resin-modified glass-1onomers. Eur J Dent. 2009;3:267-72.

22. Lohbauer U, Kramer N, Siedeschlag G, Schubert EW, Laurer $\mathrm{B}$, Müller FA, et al. Strength and wear resistance of a dental glass ionomer cement with a novel nanofilled resin coating. Am J Dent. 2011;24:124-8

23. Hankins AD, Hatch RH, Benson JH, Blen BJ, Tantbirojn D, Versluis $\mathrm{A}$. The effect of a nanofilled resin-based coating on water absorption by teeth restored with glass ionomer. JADA. 2014;145:363-70.

24. Versluis A, Tantbirojn D, Lee MS, Tu LS, DeLong R. Can hygroscopic expansion compensate polymerization shrinkage? Part I. Deformation of restored teeth. Dent Mater. 2011;27:126-33.

25. Karaoglanoglu S, Akgül N, Özdabak HN, Akgül HM. Effectiveness of surface protection for glass-ionomer, resin-modified glass-ionomer and polyacid-modified composite resins. Dent Mater J. 2009;28:96-101.

26. Kanik Ö, Turkun LS, Dasch W. In vitro abrasion of resin-coated highly viscous glass ionomer cements: a confocal laser scanning microscopy study. Clin Oral Invest. 2016;21:821-9.

27. Bonifacio CC, Werner A, Kleverlaan CJ. Coating glassionomer cements with a nanofilled resin. Acta Odontol Scand. 2012;70:471-7.

28. Pires RA, Nunes TG, Abrahams I, Hawkes GE. The role of aluminium and silicon in the setting chemistry of glass ionomer cements. $\mathrm{J}$ Mater Sci Mater Med. 2007;19:1687-92.

29. Wills MR, Hewitt CD, Sturgill BC, Savory J, Herman MM. Longterm oral or intravenous aluminum administration in rabbits. I. Renal and hepatic changes. Ann Clin Lab Sci. 1993;23:1-16.

30. Sahin G, Varol I, Temizer A. Determination of aluminum levels in the kidney, liver, and brain of mice treated with aluminum hydroxide. Biol Trace Elem Res. 1994;41:129-35

31. Monteagudo FSE, Cassidy MJD, Folb PI. Recent developments in aluminium toxicology Med Toxicol Adverse Drug Exp. 1989;4:1-16 32. Kaur A, Joshi K, Minz RW, Gill KD. Neurofilament phosphorylation and disruption: a possible mechanism of chronic aluminium toxicity in wistar rats. Toxicology. 2006;219:1-10

33. Walton JR. Brain lesions comprised of aluminum-rich cells that lack microtubules may be associated with the cognitive deficit of Alzheimer's disease. Neurotoxicology. 2009;30:1059-69
34. Gjorgievska E, Nicholson JW, Gjorgovski I, Iljovska S. Aluminium and fluoride release into artificial saliva from dental restoratives placed in teeth. J Mater Sci Mater Med. 2008;19:3163-7.

35. Czarnecka B, Limanowska-Shaw H, Nicholson JW. Buffering and ion-release by a glass-ionomer cement under nearneutral and acidic conditions. Biomaterials. 2002;23:2783-8.

36. Czarnecka B, Limanowska-Shaw H, Hatton R, Nicholson JW. Ion release by endodontic grade glass-1onomer cement, J Mater Sci Mater Med. 2007;18:649-52.

37. Okte Z, Bayrak S, Fidancı UR, Sel T. Fluoride and aluminum release from restorative materials using ion chromatography. J Appl Oral Sci. 2012;20:27-31.

38. Yamanel K. Glass ionomer cements. Turkiye Klinikleri J Restor Dent-Special Topics. 2017;3:138-50.

\section{Conflict of Interest}

Non declared. 